\title{
Abbreviations of Nietzsche's Writings
}

\author{
KGW Kritische Gesamtausgabe Werke \\ KGB Kritische Gesamtausgabe Briefwechsel \\ KSA Kritische Studienausgabe Werke \\ AOM Assorted Opinions and Maxims \\ BGE Beyond Good and Evil \\ BT The Birth of Tragedy \\ D Daybreak \\ EH Ecce Homo \\ GM On the Genealogy of Morality \\ GS The Gay Science \\ $\mathrm{HH}$ Human, All Too Human \\ $\mathrm{NL}$ Posthumous Fragments \\ TI Twilight of the Idols \\ TL On Truth and Lies in an Extra-Moral Sense
}

Detailed information on the German critical edition of Nietzsche's writings and letters which has been referential for the present work, as well as the list of the English translations of Nietzsche's writings which are cited within the volume, is provided in the final bibliography. Notes from the posthumous notebooks not available in English translation have been translated by the author.

References to the posthumous fragments are given as follows: NL year, KSA volume, note; e.g. NL 1886-87, KSA 12, 7[60]. For longer fragments, KSA page number is also provided.

References to Nietzsche's published works are given as follows: work abbreviation, section title or number (when available), aphorism or paragraph number, KSA volume, page number; e.g. GM III 12; KSA 5, p. 365. GS 354; KSA 3, p. 593. TI, “Improving” Humanity 1; KSA 6, p. 98.

All the excerpts from books whose English translation do not appear in the final bibliography (e.g. the works of Hans Kleinpeter, Afrikan Spir, Gustav Teichmüller etc.) have been translated by the author. 
